\title{
HTLV-I infection and adult T-cell leukemia in Brazil: An overview
}

\author{
Cell Markers Laboratory of Cancer Hospital - Rio de Janeiro, Brazil \\ Service of Hematology and Hemotherapy of Albert Einstein Hospital - São Paulo, Brazil \\ Department of Hematology and Hemotherapy of Hospital Santa Casa da Misericordia - São Paulo, Brazil \\ Department of Hematology of HEMOPE - Recife, Brazil
}

\begin{abstract}
Human T-cell lymphotropic Virus Type I (HTLV-I) is the etiologic factor for adult T-cell leukemia/lymphoma (ATL). HTLV-I infection can also lead to other diseases, such as HTLV-I-associated myelopathy/tropical spastic paraparesis (HAM/TSP), uveitis, arthropathy and infectious dermatitis. Studies of the infectious mode of transmission of HTLV-I and risk factors for HTLV-I-related diseases have been conducted in several countries, and differences in the prevalence, age patterns, ethnic groups and clinical presentation of the related diseases have been described worldwide. Based on the geographical characteristics of Brazil and data from the literature, we have summarized the distribution of seroprevalence in blood donors in different states around the country, as well as the incidence of ATL in regards to the endemic foci. ATL in Brazil has the same characteristics as those described elsewhere, but is reported more frequently at a younger age. In order to better evaluate ATL in Brazil, a registry has been established at the several hematologic centers under the sponsorship of the Instituto Nacional de Cancer and the Brazilian Society of Hematology and Hemotherapy, for the purpose of recording all cases originally diagnosed in Brazil.
\end{abstract}

UNITERMS: Adult T-cell leukemia/lymphoma. HTLV-I infection.

\section{INTRODUCTION}

$\mathrm{T}$ The infection and related diseases caused by human T-lymphotropic Virus Type I/II (HTLV-I) are reported worldwide, with endemic foci in southern Japan, Jamaica and other Caribbean islands, and in parts of Africa where 10 to 20 percent of the population has

\section{Address for correspondence:}

Maria do Socorro Pombo de Oliveira

Laboratório de Marcadores Celulares

Instituto Nacional do Câncer

Praça Cruz Vermelha, 23

Rio de Janeiro/RJ - Brasil - CEP 20230-030 been shown to have antibodies to the virus. ${ }^{1-3}$ Studies of the infectious mode of transmission of HTLV-I and the risk factors for HTLV-I related diseases have been conducted in several countries. ${ }^{4.5}$

Since the discovery of HLTV-I in 1980, and the increasing information about its geographical distribution in different parts of the world some serosurveys of HLTV-I have been reported in Brazil in which the endemicity of the infection has been inferred by the presence of HTLV-I associated diseases. ${ }^{6-8}$ Early findings, and the great deal of attention that have been focused on retroviruses have led to an attempt to clarify the epidemiological situation of the HTLV infection and related diseases in Brazil. Mandatory screening for HTLV antibodies in blood banks was initiated in November 1993. 
During the Second and Third International Symposiums on HTLV in Brazil, which took place in Rio de Janeiro (1992) and Recife (1993), several sessions were devoted to seroprevalence in blood donors, with discussions about the rate of seropositivity in different states of the country, but very few reports of ATL were presented $^{9}$ (and Pombo de Oliveira, unpublished observation).

The main objective of this report is to describe HTLV infection in Brazil, bringing together new information on HTLV-I and adult T-cell leukemia/ lymphoma (ATL), as well as speculating on the retrovirus origin based on the geographical distribution of different ethnic groups, social behaviour and migration within the country.

\section{UNDERSTANDING BRAZIL'S GEOGRAPHIC AND SOCIAL CHARACTERISTICS}

The geographic peculiarity of HTLV-I/II carriers in Japan, the United States and in tropical countries such as Jamaica and Colombia, has been considered to be a specific mode of HTLV-I transmission among these ethnic groups. ${ }^{10-13}$ Even in a highly endemic area, the prevalence of infection and associated diseases are variable from one particular region to another, and genetic factors might have a possible relationship to immunoresponse to HTLV-I infection. A HLA haplotype linked to the immune responsiveness to HTLV-I infection in association with ATL and HAM/ TSP has been described. ${ }^{14}$

To understand the factors that may regulate the transmission of the virus throughout Brazil, it is important to be familiar with the country's historical and geographical characteristics. The Brazilian population, the largest in South America, with 150 million inhabitants concentrated along the Eastern Seaboard, is characterized by its rapid growth, diverse origin and geographic mobility. There has been substantial migration from rural areas to the coastal cities, and a rapid growth in urban populations.

The settlement of what is now Brazil began many thousands of years ago with the arrival of the first tribes of Paleo-American Indians, migrants from North America who were probably of Asia origin. Occupying the best lands of the Amazon and Paraguay river systems and most of the coastal plains, they made up the more than 2 million native inhabitants when the Europeans arrived. Perhaps one-third of all Brazilians have some Indian ancestry, a fact particularly apparent among the people living in the mid-west, north and the northeastern regions.

As part of colonial policy, between the 16th and the 19th centuries the slave trade brought 3 to 4 million Africans to Brazil. The principal groups came from West Africa and Angola, and were dispersed all over the country in order to provide the labor required on sugar cane plantations in the Northeast, and in the mining of gold and precious stones in the Southeast.

European elements constitute a majority of the Brazilian population, a result of the influx of the Portuguese to all regions. The most numerous of the non-Portuguese European immigrants were Italians who settled in large numbers in São Paulo, Rio Grande do Sul and Espirito Santo. The less numerous immigrants were those from Spain and Middle Eastern countries such as Syria and Lebanon, as well as Jews (Ashkenazi) born in Western and Eastern European countries.

The Japanese immigrations after the World Wars I and II added further diversity to the ethnic mix. In contrast to the Mediterranean peoples, it took three generations for the Japanese community to become assimilated. Besides the wider cultural gap that separated them from the general population, they were for many years physically isolated in rural areas of São Paulo, Paraná and Mato Grosso.

Today, the darker-skinned members of the population tend to be at the lower end of the economic hierarchy. This situation is said to be due to the perpetuation of generations of blacks in regions that offer fewer economic and social opportunities. Blacks are more numerous in the states of Bahia, Rio de Janeiro, Pernambuco, Maranhão and Minas Gerais.

\section{AN UPDATE OF HTLV EPIDEMIOLOGICAL STUDIES IN BRAZIL}

The first study of HTLV-I infection in Brazil was conducted by Kitagawa et al., who reported on the prevalence of antibodies to HTLV-I in Japanese immigrants from Okinawa living in Campo Grande, Mato Grosso. Serum samples from 46 Japanese immigrants (Isei) and 50 offsprings (Nisei), and 51 Japanese immigrants (not from Okinawa) living in São Paulo, were analyzed for HTLV-I antibodies. This study 
Table 1

Profile of HTLV-I/II studies performed in Brazil

\begin{tabular}{|c|c|c|c|c|}
\hline $\begin{array}{l}\text { Characteristics } \\
\text { of group studied }\end{array}$ & $\begin{array}{l}\text { Number } \\
\text { of cases }\end{array}$ & $(+)^{H}$ & HTLV-I & Source \\
\hline Japanese immigrants & 141 & 10 & 7.00 & Kitagawa et al. 1986 \\
\hline from Okinawa and & 96 & 10 & 10.00 & \\
\hline other areas of Japan & 51 & 0 & 0.00 & \\
\hline Blood donors, RJ & 2,138 & 9 & 0.42 & Lee et al. 1989 \\
\hline $\begin{array}{l}\text { Patients at high } \\
\text { risk for retroviroses } \\
\text { from RJ, SP, MG }\end{array}$ & 548 & 20 & 3.60 & Cortes et al. 1989 \\
\hline $\begin{array}{l}\text { Patients with } \\
\text { malignant diseases, RJ }\end{array}$ & 215 & 8 & 3.70 & Serpa et al. 1989 \\
\hline Indians and & 137 & 43 & 31.30 & Nagauchi et al. 1990 \\
\hline cancer patients & 43 & 10 & 23.20 & \\
\hline from Belem, PA & 280 & 53 & 18.90 & \\
\hline $\begin{array}{l}\text { Patients from SP with } \\
\text { neurological disorders }\end{array}$ & 150 & 46 & 30.60 & Franca et al. 1990 \\
\hline Patients with ATL, RJ & 14 & 11 & 79.00 & Oliveira et al. 1990 \\
\hline $\begin{array}{l}\text { Healthy individuals } \\
\text { from Ceara }\end{array}$ & 593 & 3 & 0.50 & Costa et al. 1991 \\
\hline $\begin{array}{l}\text { Patients with a } \\
\text { malaria risk, PA }\end{array}$ & 186 & 2 & 1.00 & Lal et al. 1992 \\
\hline $\begin{array}{l}\text { Indians from } 13 \text { tribes, } \\
\text { AM, PA, MT }\end{array}$ & 624 & 109 & 17.00 & Maloney et al. 1992 \\
\hline $\begin{array}{l}\text { Healthy individuals } \\
\text { and patients, BA }\end{array}$ & $\begin{array}{l}327 \\
337\end{array}$ & $\begin{array}{r}6 \\
62\end{array}$ & $\begin{array}{r}1.80 \\
18.40\end{array}$ & Moreira et al. 1993 \\
\hline Blood donors, MG & 2,100 & 10 & 0.50 & Proietti et al. 1994 \\
\hline Blood donors, SP & 17,063 & 30 & 0.17 & Ferreira Jr. et al. 1994 \\
\hline
\end{tabular}

Since the begining of 1990 , several studies have been conducted regarding the occurence of HTLV-I infection among both urban and isolated populations in Brazil. Indian communities living in the Amazon region were found to be positive for HTLV-I and II, as well as were individuals treated for malaria at clinics in the state of Para, and hospitalized patients in Bahia. The prevalency rate in these groups range from 1.8 to 31.4 percent, ${ }^{9.17-22}$ as summarized in Table 1.

Recently, MALONEY et al. tested plasma and cell pellets from Kayapo and Krano Indians of all ages using a polymerase chain reaction, revealing overall HTLV-II prevalency rates of 33.3 and 12.2 percent, respectively, with increasing prevalence amongst the older and female participants. The Indians of these tribes had had little contact with outside groups, and so this data helped to postulate that HTLV-II could be an ancient, New World human virus. ${ }^{23}$

These studies lead the National Health Service to establish guidelines for serological tests to screen HTLVI/II antibodies in blood donors. Routine screening of blood donors has been performed in all blood centers in Brazil since November

revealed that ten of $96(10 \%)$ Isei and Nisei from Okinawa were HTLV-I positive, while all of the 51 immigrants from other parts of Japan were seronegative. ${ }^{15}$

Later, in 1987, the incidence of HTLV-I was evaluated among 116 Guajajara Indians in Maranhão, and 44 patients with hematological disease in Rio de Janeiro. All these samples were seronegative, leading to the incorrect conclusion that HTLV-I infection was not endemic in Brazil. ${ }^{16}$ Then, a study performed in groups at risk for Acquired Immunodeficiency Syndrome (AIDS) from Rio de Janeiro, Minas Gerais and São Paulo, showed that the prevalence of HTLV-I antibodies ranged from 1 to 13 percent among blood donors, homosexual men, prostitutes, and hemophiliacs and their wives. ${ }^{6}$
1993, and the preliminary results demonstrate the presence of HTLV-I/II with prevalence ranging from 0.17 to 1.8 percent. These varying percentages may be a reflection of differences in sample sizes and methodology, as well as in the socio-economic status and ethnicity of the populations, according to the reports of the Third International Symposium on HTLV in Brazil, held in Recife in September 1994 (Table 2).

Curiously, MINIZ et al. studied 172 individuals over 15-years old from an isolated African community in Espirito Santo (Southeast), and found two females aged 50 and 80 , seropositive (WB) to HTLV-I, for a prevalence of 1.1 percent. Further, Veronesi et al. carried out a new seroprevalence survey of Japanese immigrants from Okinawa, living in the northeast region of São Paulo, and found a rate of 13 percent 
Table 2

Seroprevalence studies of HTLC-1/II in blood banks*

\begin{tabular}{lccccc}
\hline Blood Bank & Year & $\begin{array}{c}\text { Number of } \\
\text { samples }\end{array}$ & $\begin{array}{c}\text { HTLV-I/II } \\
\text { ELISAWB }\end{array}$ & $(\%)$ & Source \\
\hline HEMO-AM & 1994 & 1,200 & 1 & 0.08 & Health Ministry \\
HEMO-PA & 1990 & 809 & 4 & 0.49 & Dr. Saraiva \\
HEMO-RJ & 1993 & 15,318 & 66 & 0.43 & Dr. Reis \\
HEMO-SP & 1993 & 46,183 & 217 & 0.47 & Dr. Alquezar \\
Santa Casa-SP & 1993 & 10,535 & 89 & 0.84 & Dr. Gomes \\
HEMO-CE & 1993 & 10,535 & 89 & 0.84 & Dr. Gomes \\
HEMO-PR & 1994 & 29,903 & 39 & 0.13 & Dr. Baldanzi \\
SSE-RG & 1994 & 4,991 & 21 & 0.42 & Dr. Mena-Barreto \\
HEMO-PE & 1994 & 45,747 & 376 & 0.82 & Dr. Schneiber \\
HEMO-MG & 1994 & 1,877 & 6 & 0.32 & Dr. Proietti \\
HEMO-BA & 1994 & 1,040 & 14 & 1.35 & Health Ministry \\
\hline
\end{tabular}

* Data from reports of the second and third International Symposium of HTLV in Brazil.

seropositive in the total group of Isei and their offspring.

In the general population over 30-years old, the prevalency rates of HTLV-I antibodies among females are consistently higher than males. Such discrepancies by gender have been noted in Japan and Jamaica, and are due to the transmission of HTLV-I from male to female by sexual contact, as well as to infection via blood transfusion, which is administered more frequently to females than to males. ${ }^{5.24}$ It is worthwhile to mention that the studies carried out on blood donors have an epidemiologic bias, as females are potential carriers of this virus, but they tend to be the minority cases $(9: 1)$ in these studies.

Although a minority of individuals infected with HTLV-I will develop ATL, prospective studies are necessary to identify with precision the main route of transmission of HTLV in Brazil, and the risk factors for the development of ATL in carriers.

\section{THE POSSIBLE ROUTE AND MOLECULAR EPIDEMIOLOGY OF HTLV-I INFECTION}

The HTLVs are classified as a Type $\mathrm{C}$ retrovirus on the basis of their budding in ultra-morphology. HTLV-I and HTLV-II are closely related viruses. ${ }^{25}$ Serosurveys conducted on various populations worldwide have used different sampling schemes, as well as different serologic assays, with varying sensitivity and specificity. Therefore, the seroprevalence rate between these two viruses has been difficult to compare. However, the more recent use of tests that allow for differentiation between them, in addition to the isolation and molecular characterization of HTLV-I and II in different populations, has been providing new insight into the geographical distribution of the HTLVs. ${ }^{10,26}$

So far, four subtypes of HTLV-I and two of HTLVII have been identified: The HTLV-I, Subtype I, comprises mainly African strains; Subtype 2 are isolates from different parts of the world; Subtype 3 includes mainly Japanese isolates; and subtype 4 consists of isolates from Australia and Malaysia that are the most divergent from the other subtypes on the nucleotide sequence (up to 8 percent). The two subtypes of HTLV-II are the protype isolate HTLV-IIMo (Subtype A) and NLA (Subtype B), which differ by 5 percent. Both are found in intravenous drug abusers, and Subtype B bas been found in North American Indians. ${ }^{26}$

Based on its demographic profile, it is highly probable that HTLV-I/II came to Brazil via one or more of three following routes: 1) HTLV-I/II was already present in the native Amerindian population that came from Asia, 2) it arrived later through the trading of African slaves, or lastly, 3) by the Japanese immigration 
in the begining of the 1900s's (Fig. 1). The HTLV-I strains obtained in Brazil thus far show that 5 out of 6 isolated from a tight cluster, and are distinct from Japanese and Caribbean isolates. ${ }^{27}$ However, SEGUARDO et al. has recently demonstrated that the genomic variation of HTLV-I strains among patients with HAM/TSP and HTLV-I, asymptomatic carriers from São Paulo city, were HTLV-I Subtype II; the same variant founded in patients from the Caribbean region (data presented at the Third International Symposium on HTLV in Brazil).

\section{THE PATHOGENESIS OF HTLV-I INFECTION AND THE DEVELOPMENT OF ATL}

The molecular and biological aspects of HTLV-I are important in the pathogenesis of adult T-cell leukemia/lymphoma (ATL) and HTLV-I associated myelopathy (HAM/TSP). Differences in age patterns in ethnic groups, and in the clinical presentation of these related diseases, have been described worldwide. The reasons for these differences are unknown, and the most reasonable hypothesis is that these differences may be due to genetic modifiers and environmental factors, rather than to different strains of HTLV-I. ${ }^{12.13}$
Although the precise nature of the interactions between viral products and cellular transcription factors in the pathogenesis of ATL is still unclear, the tax and envelope proteins of HTLV-I are both implicated in inducing T-cell proliferation. Molecular cloning of HTLV-I showed that the proviral DNA is flanked by 5 'and 3' long terminal repeats (LTRs) integrated into cellular DNA. ${ }^{28}$

Tax is a protein $\left(\mathrm{p} 40^{\operatorname{tax}}\right)$ that transactivates transcription activation of the viral LTR from a number of cellular genes such as transcriptase factors (EGR-1,EGR$2, \mathrm{c}$-fos),membrane receptors (á-chain of $\mathrm{IL}-2$ receptor as well as IL-2 â-chain p75), and interleukines (IL-2, IL-4, IL-6,IL-9, GM-CSF, MID-1á). ${ }^{25.29}$

As a result of cellular gene activation, HTLV-I is capable of activating naïve T-cells from a slight to a high proliferation. Tax does not bind directly to the enhancer DNAs, and there are no homologies between tax and any other known oncogene. ${ }^{30}$

It is well known that HTLV-I infected cells pass through a series of molecular changes leading to the leukemic state, and a multistage period is implicated in the development of ATL. ${ }^{22.31}$ Carriers of the HTLVI virus have poor mediated immunity and behavior of immune deficiency syndrome, and are susceptible to opportunistic infections, suggesting that certain infections may be acting as cofactors in the progression to ATL. ${ }^{32.33}$

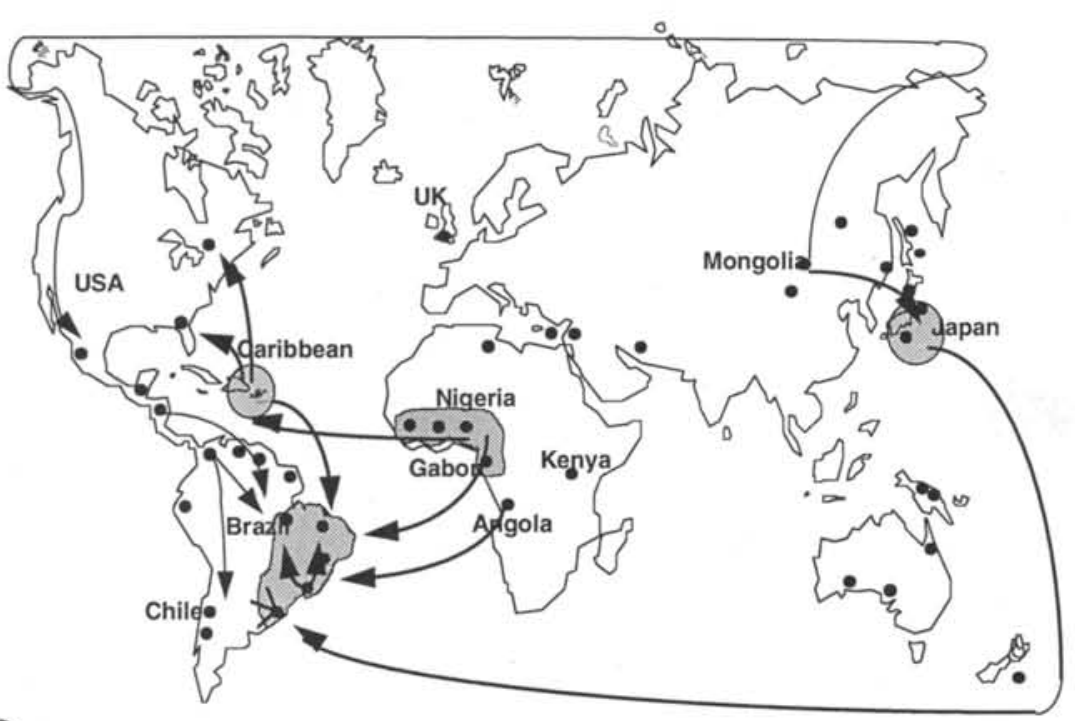

Endemical area of HTLV-I/II

Possible routes of first migrations

Trade of African slaves and Japanese immigrations

ATL was first described clinically in Japan in 1977 by TAKATSUKI et al. ${ }^{34}$ Later, this malignancy was found to be associated with HTLV-I, ${ }^{35}$ based on several parameters, such as geographical clusters of high incidences of ATL corresponding to a high prevalence of HTLV-I infection; that HTLV-I immortalises human $\mathrm{T}$ cells (CD4+), and mainly, that HTLV-I proviral DNA is found in ATL abnormal lymphoid cells. All patients with ATL have antibodies against HTLV-I. ${ }^{36,37}$

The clinical features of ATL include enlargement of the lymph nodes, liver and spleen, frequent skin lesions, hypercalcemia and a high incidence of opportunistic infections. ATL often presents a leukemic feature, but lymphoma is very frequent in Caribbean people. Peripheral blood smears usually

Figure 1 - Possible routes of HTLV-I/II to Brasil 


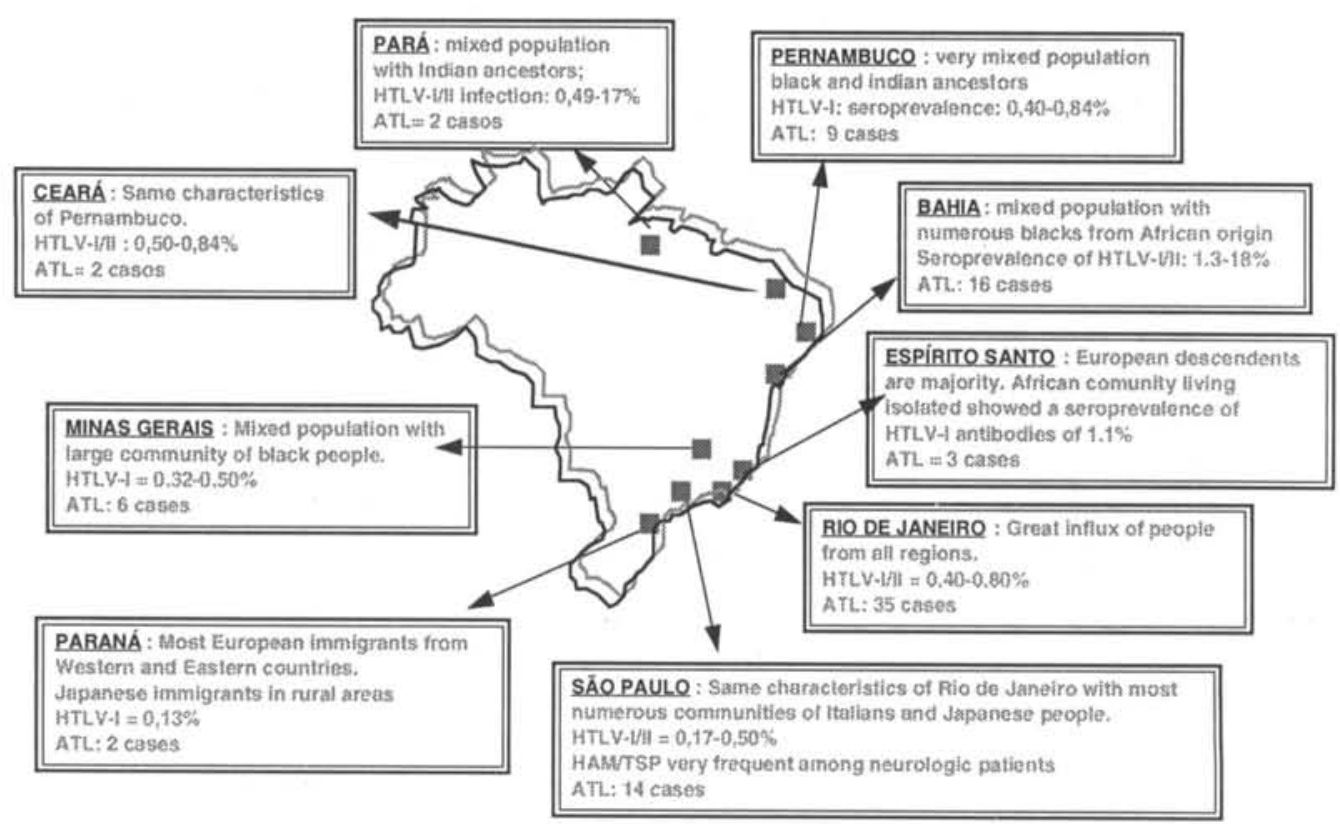

Figure 2 - HTLV-I and ATL in Brazil.

show pleomorphic lymphocytes with convoluted nuclei, which may resemble Sézary cells and other polilubulated, so-called flower cells. Histologies of lymph nodes and skin lesion specimens are not pathognomonic, but are mainly characterized as pleomorphic, large-cell lymphoma or mixed large- and small-cell lymphoma. It has been recognized that ATL encompasses a variety of clinical presentations which are sometimes difficult to distinguish in some cutaneous T-cell lymphomas (CTcL), such as mycosis fungoides and Sezary syndrome (MF/ $\mathrm{SS}$ ), and in other forms of peripheral T-cell nonHodgkin's lymphoma. ${ }^{10.38 .39}$

It is currently clear that HTLV-I infection is a direct cause of ATL, and that mother-to-child transmission of HTLV-I has been the main route of infection leading to ATL. This fact implies that surrounding the reported ATL cases, we may identify a relatively large population of infected individuals. In addition, it is important to quantify the risk for ATL in the HTLV-I infected population and to clarify the frequency of ATL among other T-cell disorders, as geographical differences in the frequency of clinical manifestations and various immunopathological forms of ATL have been described worldwide.

Because of the overlapping features between ATL and other T-lymphoproliferative disorders, the diagnosis of ATL is based on a multiparameter approach that takes into account clinical and laboratory parameters, such as hypercalcemia, the morphology of the abnormal lymphoid cells, the expression of CD25 on the cell membrane, HTLV-I serology and the monoclonal integration of HTLV-I proviral DNA in the malignant cells. ${ }^{18,40}$

\section{ATL IN BRAZIL}

T-cell malignancies in Brazil have a high seroprevalence rate of HTLV-I antibodies. ${ }^{41}$ In 1990, 14 patients with ATL were identified in Rio de Janeiro over a two-year period. At the same time, SPINA-FRANCA et al. reported a high incidence of HAM/TSP in São Paulo, and it become apparent that HTLV-I related disease is frequent in Brazil. ${ }^{7.8}$

Although detailed studies in Japan ${ }^{42}$ and Jamaica have provided important data on pathological and epidemiological chracteristics of ATL, Brazil has been hampered by difficulties in the diagnosis of this disease.

Recently, we investigated 188 patients with Tcell diseases, based on clinical and laboratorial findings, to discriminate the clinicopathological differences between HTLV-I positive and negative cases. ${ }^{43}$ We found that 54 of the 188 cases were ATL in different clinical forms. Cases evaluated in this study were referred from several sources and a questionnaire recording date and place of birth, as well as demographic features and laboratorial data, was requested from referring physicians. A case definition 
was applied following the Matutes and Catovsky score system. ${ }^{18}$

Taking into account the data of the 54 cases identified at the Cancer Hospital, and the 35 patients identified through the Brazilian literature search, ATL was particularly prominent in a geographic area of increased HTLV-I prevalence, as shown in Figure 3. High prevalences of HTLV infection and ATL cases were recorded in the state of Rio de Janeiro (35 cases), Bahia (16), São Paulo (14), Pernambuco (9), Minas Gerais (6 ); followed by Espirito Santo (3), Ceará (2), Pará (2) and Parana (2).

ATL in Brazil has the same characteristics as those described elsewhere, with the apparent difference between Brazilian, Japanese and Caribbean cases being age. The Brazilian patients were younger than Japanese ( 1.8 to 71 , medium of 41 years). In 50 percent of these patients, skin lesions such as erythema, plaque and cutaneous nodules were the main disease manifestation.

The value of a systematic screening of HTLV-I in these cases was that it disclosed ATL cases which had been confused with other lymphoproliferative disorders, and, in particular, with cutaneous T-cell lymphoma and/or the pure lymphoma forms. ${ }^{31}$ Because of the similarities between ATL and cutaneous lymphoma (CTcL), both groups were compared, and the outstanding differences between them were: male predominance in $\mathrm{CTcL}$, leukemia and hypercalcemia in ATL, but low in CTcL; the phenotype in 92 percent of ATL cases overexpressed CD4/CD25, and in CTcL only six cases were CD4/ $\mathrm{CD} 25+$; poor prognosis in ATL with median survival of 6 months, but good prognosis in $\mathrm{CTcL}$ with survival of 36 to 70 months. Proviral DNA of HTLVI was demonstrated in tumor cells of ATL cases, but failed to be demonstrated in CTcL.

In these series, three patients, two males and one female, with the diagnosis of ATL smouldering and chronic type, had: difficulty in walking; sphincter disturbance; spastic paraparesis lower-limb hyperreflexia; and brisk reflexes. All these clinical signs fulfilled the diagnosis of HAM/TSP concomitantly to ATL.
To confirm the significance of intra-familial transmission of HTLV-I infection among patients with ATL $(n=19)$ and other infected individuals (HAM/ TSP, $n=7$, politransfused patients, $n=8$ ), we also studied 93 family members of 34 patients, distributed as follows: 24 husbands and/or wives, 12 mothers, two fathers, 25 sons and daughters, and 30 siblings.

HTLV-I antibodies were found in 8/12 (66.6 percent) of mothers of ATL patients, as well as in 16/ 24 (66.6 percent) of husbands or wives of ATL and HAM/TSP patients. The interesting thing is that mother-to-child transmission was not the main route of HTLV-I infection in four patients with ATL, as their mothers were negative. Three patients were breast-fed by an "ama de leite," or wetnurse, and one patient had received several blood transfusions during childhood for sickle-cell disease.

For two patients, a familial study was performed on their husbands (both HTLV-I+), siblings (all HTLVI negative), and children. The mothers of these patients were not studied, as they were deceased. We believe that both patients were contaminated by their husbands, based on the fact that all their siblings were negative, and that two of their children, ages 17 and 24 , were positive. Two patients with ATL had two sisters with HAM/TSP. One case was mentioned above, as the patient had both chronic-type ATL and $\mathrm{HAM} / \mathrm{TSP}^{4}$

In order to characterize ATL cases, The Brazilian Group for the Study of ATL has recently set up a registry for the purpose of recording patients with ATL diagnosed in different Brazilian states. This potencial case collection and laboratory evaluation will provide important biological information about HTLV-I infection and the geographic cofactors to the development of ATL.

Note: Since the review of this manuscript several reports have been published regarding HTLV-I and HTLV-II infectionsin Brazil. In addition, the brazilian group for the study of ATL has recorded 134 cases of ATL in different clinical sub-types. These cases were diagnosed in Rio de Janeiro, São Paulo, Salvador, Porto Alegre, Recife and Fortaleza. 


\section{ReSUMO}

Desde o descobrimento e caracterização do vírus linfotrópico de célula T-humana do tipo I (HTLV-I) e a sua associação com linfoma do tipo T e mielopatia espastica, muito avanços foram alcançados quanto aos aspectos filogenéticos e patogenicos desta infecção retroviral. A infecção pelo HTLV-I pode ser causodora de outras doenças como uveite, artropatia, dermatite infecciosa, alem da leucemia/linfoma de celulas T do adulto (ATL) e da paraparesia espastica tropical associada ao HTLV-I (HAM/TSP). Os modos de transmissāo da infecção sāo semelhantes ao demais retrovirus, porem diferentes grupos etnicos tem sido considerados como de maior incidencia de infecçāo e doenças associadas. Estudos sorológicos e moleculares vem sido realizados em diversos países do mundo em busca de co-fatores responsaveis pela eficiencia da transmissāo de infecção em diferentes faixas etárias e em grupos etnicos distintos. Baseados no perfil demográfico do Brazil e nos resultados dos trabalhos cientificos realizados sobre HTLV-I/II e descritos na literatura nos sumarizamos nesta revisão, os dados soroepidemiológicos registrados nos bancos de sangue de diversos Estados brasileiros bem como a incidencia de ATL em relação a area georafica do Brazil afetada pela infecção. Os casos de ATL já estudados no Brasil, tem as mesmas caracteristicas clinicopatológicas dos casos descritos na literatura internacional. No entanto, o perfil demográfico dos casos brasileiros se caracteriza por idade mais jovem. Com o ojetivo de proporcionar um registro de casos de ATL, foi criado o Grupo Brasileiro para estudo de ATL. Os resultados dos estudos deste grupo poderão fornecer uma melhor avaliação da patogenese da ATL $e$ dos mecanismos de transmissão do HTLV-I no Brasil.

\section{REFERENCES}

1. Blattner WA, Kalyanaraman VS, Robert-Gurof M. The human Type $\mathrm{C}$ retrovirus, HTLV, in blacks from the Caribbean region and relationship to adult T-cell leukemia/ lymphoma. Int J Cancer 1982;30:257-64.

2. Himuna $\mathrm{Y}, \mathrm{Komoda} \mathrm{H}, \mathrm{Chosa} \mathrm{T}$. Antibodies to adult T-cell leukemia-virus associated antigen (ATL) in sera from patients with ATL and controls in Japan: a nationwide seroepidemiological study. Int J Cancer 1982;29:631-35.

3. Kohakura M, Nakada K, Yonahara M. Seropidemioloy of the human retrovirus (HTLV/ATLV) in Okinawa where adult t-cell leukemia/lymphoma is highly endemic. Gann 1986;77:21-3.

4. Cavalcanti M, Ferreira O, Puccioni M, Novis S, Schechter M. HTLV-I associated neurologic manifestations in four generations of a Brazilian family. J AIDS 1993;6:213-17.

5. Tajima K, Tomiga S, Suchi T. Epidemiological analysis of the distribution of antibody to adult T-cell leukemia virus associated antigen: Possible horizontal transmission of adult T-cell leukemia virus. Gann 1982:73:893-901.

6. Cortes E, Detels R, Aboulafia D, et al. HIV-1, HIV-2, and HTLV-I infection in high-risk groups in Brazil. N Engl J Med 1989;320:953-8.

7. Pombo de Oliveira MS, Matutes E, Famadas LC. Adult Tcell leukaemia/lymphoma in Brazil and its relation to HTLV-I. Lancet 1990:336:987-90
8. Spina-Franca A, Livramento JA, Machado LR, Gomes HR. HTLV-I antibodies in serum and cerebrospinal fluid in tropical spastic paraparesis in Brazil. Arquivos de NeuroPsiquiatria 1991;48:441-7.

9. Matutes E, Schulz T, Andrada Serpa MJ, Campos-Araujo AQ, Pombo de Oliveira MS. Report of the Second International Symposium on HLTV in Brazil. Leukemia, 1994;8:1092-4.

10. Blattner W.A Epidemiology of HTLV-I and associated diseases In: Blattner WA, ed. Human Retrovirology: HTLV. New York: Raven Press, 1990:251-65.

11. Gibbs WN, Lofters W, Campbell M, et al. Non-Hodgkin Lymphoma in Jamaica and its relation to adult T-cell leukemia-lymphoma. Annal Inter Med 1987;106:361-8.

12. Hanchard B, Gibbs WN, Lofters W. Adult T-cell leukemia/ lymphoma (ATL) in Jamaica. In: WA Blattner, ed. Human Retrovirology: HTLV. New York: Raven Press, 1990:197383.

13. Levine PH, Jaffe ES, Manns A, Murphy EL, Clark J, Blattner WA. Human T-cell leukemia virus type I and adult T-cell leukemia/lymphoma outside Japan and the Caribbean Basin. Yale J Biol Med 1988;61:215-22.

14. Sonoda S. Genetic and immunologic determinants of HTLV-I associated diseases 1990. In: Blattner WA, ed. Human Retrovirology: HTLV. New York: Raven Press, 1990:315-26.

15. Kitagawa T, Fujishita M, Tagushi H, Miyoshi I, Tadokoro H. Antibodies to HTLV-I in Japanese immigrants in Brazil. JAMA 1986;256:2342 
16. Andrada-Serpa MJ, Dobbin JA, Gomes P, et al. Immunology Letters 1988;18:15-8.

17. Lal RB, Povoa M, Lal AA. Seroprevalence of HTLV-II in Pragaminos, State of Para, Brazil. J AIDS 1992;5:634-5.

18. Matutes E, Catovsky D. Adult T cell leukaemia lymphoma. In: Whittaker JA, ed. Leukemia (2nd ed). Oxford: Blackwell Scientific Publications, 1992;416-33.

19. Moreira ED, Harrington W, Ribeiro TP. HTLV-II and a new endemic area for HTLV-I in Brazil. Revista da Sociedade Brasileira de Medicina Tropical 1992;25:141-3.

20. Moreira, ED, Ribeiro TP, Swanson P. Seroepidemiology of human T-cell lymphotropic virus type I/II in Northeastern Brazil. J AIDS 1993;6:959-63.

21. Nakauchi CM, Linhares AC, Maruyama K, et al. Prevalence of human T cell leukemia virus (HTLV-I) antibody among populations living in the Amazon region of Brazil (preliminary report). Mem Inst Oswaldo Cruz, Rio de Janeiro, 1990;85:29-33.

22. Nerukar LS, Wong-Staal F, Gallo RC. Human retroviruses, leukemia and AIDS. In: Henderson ES, ed. Leukemia. Philadelphia: WB Saunders, 1990:225-52.

23. Maloney EM, Biggar RJ, Neel JV, et al. Endemic human T cell lymphotropic virus type II infection among isolated Brazilian Amerindians. J Infec Dis 1992;166:100-7.

24. Chavance M, Ferry N, Valette I, Schaffar-Deshayes L, Montplaisir N. Sex ratio of human T-lymphotropic virus type I infection and blood transfusion. Am J Epidemiol 1990;131:395-9.

25. Schulz T, Weber J. The biology of the human Tlymphotropic viruses types 1 and 2 (HTLV-1, HTLV-2). In: AIDS and the new viruses. Oxford: Scientific Publications, 1990:125-62.

26. Hall WW, Kubo T, Ijichi S, Takahashi H, Zhu SW. Human $\mathrm{T}$ cell leukemia/lymphoma virus, type II (HTLV-II): Emergence of an important newly recognized pathogen. Sem Vir 1994;5:165-78.

27. Schulz T, Calabro ML, Hoad JG. HTLV-1 envelope sequences from Brazil, the Caribbean, and Romania: clustering of sequences according to geographic origin and variability in an antibody epitope. Virology 1991;184:483-91.

28. Seiki M, Hattori S, Yoshida M. Human adult T-cell leukemia virus: molecular cloning of the provirus DNA and the unique terminal structure. Proc Natl Acad Sci USA 1982;79:6,899-902.

29. Felber BK, Paskalis H, Kleinman-Ewing C. The $\mathrm{pX}$ protein of HTLV-I is a transcriptional activator of its long terminal repeats. Science 1985;229:675-8.
30. Watanabe S, Seiki M, Tsujimoto H, Miyoshi I, Hayami M Yoshida M 1985. Sequence homology of the simian retrovirus genome with human T-cell leukemia virus type I. Virology 1985;144:59-65.

31. Yamaguchi K, Kiyokawa T, Futami G, Ishii T, Takatsuki K. Pathogenesis of adult T-cell leukemia from clinical pathologic features. In: Blattner WA, ed. Human Retrovirology: HTLV. New York: Raven Press, 1990:163-71.

32. Taguchi H, Miyoshi I. Immune suppression in HTLV-I carriers: a predictive sign of adult T-cell leukemia. Acta Med Okayama 1989;43:317-21.

33. Yamaguchi K, Matutes E, Catovsky D, Galton DAG, Nakada K, Takatsuki K. Strongyloiges stercoralis as candidate cofactor for HTLV-I induced malignancies. Lancet 1987;II:94-5.

34. Uchiyama T, Yodoi J, Sagawa K, Takatsuki K, Uchino H. Adult T-cell leukemia: clinical and hematologic features of 16 cases. Blood 1977;50:481-92.

35. Poiez BJ, Ruscetti FW, Gazdar AF, Gallo R. Detection and isolation of type $\mathrm{C}$ retrovirus particles from fresh and cultured lymphocytes of a patients with cutaneos T-cell lymphoma. Proc Natl Acad Sc USA 1980;81:7415-9.

36. Seiki M, HattoriS, Hirayama Y, Yoshida M. Human adult T-cell leukemia virus: complete nucleotide sequence of the provirus genome integretad in leukemic cell DNA. Proc Natl Acad Sci USA 1983;80:3,618-22.

37. Yamaguchi K. Human T-lymphotropic virus type I in Japan. iancet 1994:343:213-16.

38. Takatsuki K, Yamaguchi K, Kawano F. Clinical diversity in adult T-cell leukemia-lymphoma. Cancer Res 1985;45:4644-5.

39. Kawano F, Yamaguchi K, Nishimura H, Tsuda H, Takatsuki $\mathrm{K}$. Variation in the clinical courses of adult T-cell leukemia. Cancer 1985;55:851-6

40. Levine PH, Cleghon F, Manns A, Jaffe E, Roman L, Blattner WA. A working point-score classification of adult T-cell leukemia/lymphoma for epidemiologic studies. Int J Cancer 1994;59:491-3.

41. Carvalho SMF, Pombo de Oliveira MS, Bezerra ACS, et al. HTLV-I/II in hematological and cancer patients in Rio de Janeiro, Brazil. Blood 1993;82(suppl):624a.

42. Shimoyama M. Diagnostic criteria and classification of clinical subtypes of adult T -cell leukemia-lymphoma. A report from the Lymphoma study group, 1984-87. British J Haematology 1991;79:428-37.

43. Pombo de Oliveira MS, Matutes E, Schulz T. T-cell malignancies in Brazil. Clinico-pathological and molecular studies of HTLV-I positive and negative cases. Int J Cancer 1994;60:823-7. 